\title{
INDUSTRY 4.0: HORIZONTAL INTEGRATION AND INTELLECTUAL PROPERTy LAW STRATEGIES IN ENGLAND
}

\author{
Marcelo Negri Soares* \\ Marcos Kauffman**
}

\begin{abstract}
1 Introduction. 2 Industry 4.0. 3 The Impact of I4.0 on Businesses. 3.1 The Intellectual Property World Map and Brazil's Distance from the Fourth Industrial Revolution Protagonists. 4 Intellectual Property. 4.1 The Implications for Intellectual Property. 4.2 The Integrated Life Cycle - Model Based Definitions. 4.3 Digital Businesses and the Human Cloud. 4.4 Horizontally Integrated Businesses and the Value of Data. 5 The Need to Adapt IP Strategies. 5.1 Business Strategy Recommendations. 5.1.1 A Look at Competitors' Patents. 5.1.2 The Growing Importance of IPR. 5.2 Intellectual Property Recommendations: Life Cycle Recommendations. 5.2.1 Always Use NDAs (Non-Disclosure Agreements). 5.2.2 Always Share Only the Necessary Layers Information. 5.2.3 Always Use Confidentiality Notices. 5.3 Human Cloud Recommendations. 5.3.1 Use Non-Disclosure Clauses in Employment and Contractor Contracts. 5.3.2 Implementation and Physical Security Measures. 5.4 Data Sharing Recommendations. 5.4.1 Categorization of the Different Data Types. 5.4.2 Data Ownership Rights. 5.5 IP Ownership Clauses. 6 Conclusion. References.
\end{abstract}

\begin{abstract}
Intellectual Property (IP) is increasingly recognised as a paramount intangible asset influencing the value of companies, as well as their corporate strategies and management. This paper focuses on the impact of implementing Industry 4.0 (I4.0) on the management of IP in collaborative inter-organisational interconnected networks. Such interconnected networks will allow groups of companies, often competitors and/or customers, to share data and to collaborate in the design, development and manufacture of complex products and/or services, exchanging large amounts of proprietary technical data. Furthermore, this paper explores how companies can benefit from the interconnected network capabilities, whilst protecting them from any risks regarding the vulnerability of IP assets to misappropriation, unauthorized use or leakage. The

* $\quad$ Lawyer, Accountant, Teacher and Writer. Post-Doctorate from Universidade Nove de Julho - São Paulo (2017). PhD in Law from Pontifícia Universidade Católica de São Paulo (2013). Master by the same PUC-SP (2005). Graduated in Law from the State University of Maringá, Paraná (1997). Specialist in Procedural Law at the Paulista University (1998), in Commercial Law at Mackenzie (2006), in Public Law at the Federal School of Law (2008) and Accounting at the Maringá State Institute of Education (1989). Professor of the Stricto Sensu Post-graduation Program in Legal Sciences at Unicesumar. Researcher at FAPESP and at ICETI - Cesumar Institute of Science, Technology and Innovation. E-mail: <negri@negrisoares.com.br>.http://orcid.org/0000-0002-0067-3163

** Doctorate Student, Centre for Business in Society - Faculty of Business and Law - Coventry University. Coventry University-U.K./Centre for Business in Society - Faculty of Business and Law. E-mail: <marcos.e.kauffman@gmail.com>. https://orcid.org/0000-0002-5465-2368
\end{abstract}


focus of this study is the UK manufacturing industry, where formal contractual tools are being deployed to support IP management in collaborative projects. It relies on an in-depth study of IP management practices in the UK manufacturing supply chain to critically assess the current state of practice in order to provide answers to the risks emanating from IP management in this new and complex collaborative setting. This paper concludes that IP and contractual tools deployed in this new environment must be underpinned by the business strategy and the business model. In addition, changes to organisational structures are necessary to bring together functions that typically operate in silos in many manufacturing businesses, namely: Engineering, Information Technology, Commercial and Legal Departments.

Keywords: Fourth Industrial Revolution. Intellectual Property. Business Strategy. Intellectual Property Strategy.

\section{INTRODUCTION}

The Fourth Industrial Revolution, also known as Industry 4.0 (I4.0), is described as a "digital revolution" in which the deployment of the Internet of Things (IoT) and the interconnecting of all things and businesses in the manufacturing industry leads to "blurring the lines between the physical and digital spheres" (SCHWAB, 2016, p. 9). Such paradigm shift comes along with the prospect of disrupting the global manufacturing industry and leading to substantial economic growth and prosperity (MAN; STRANDHAGEN, 2017, p. 721).

The available literature indicates that the levels of integration of the I4.0 and data exchange between businesses will lead to extensive organisational consequences resulting in risks and opportunities to the manufacturing business (BAUERNHANSL; HOMPEL; VOGEL-HEUSER, 2014; BOTTHOF, 2015). Furthermore, it also recognises that established manufacturers will be required to re-evaluate and innovate their Business Models (BM) in order to stay competitive (JONDA, 2007; KAGERMANN, 2015; LOEBBECKE; PICOT, 2015), as the phenomenon will lead to new ways of creating value and disrupting the current supply chain structures (KAGERMANN, 2015). Finally, the literature also points out that there is a backlog in business management research regarding the impact on current business (BRETTEL et al., 2014; EMMRICH et al., 2015).

Therefore, as manufacturing businesses embark in the Fourth Industrial Revolution and go digital, the key questions troubling many practitioners and businesses managers are:

What will be the impact on business? How will intellectual property (IP) and IP strategies be affected by the new interconnect environment associated with I4.0?

This paper proposes that, in order to answer these questions, business leaders, academics and IP law practitioners must understand the changes taking place and then adapt their practices and strategies in order to mitigate any risks and capture and secure value in the form of IP. Furthermore, it is also argued that the failure to recognise and adapt to the new industrial 
paradigm will result in a failure to secure a sustainable future and long-term business growth.

This article aims to contribute to the literature by assessing the concept of Industry 4.0 and its impact on manufacturing business and its Intellectual Property Strategies.

\section{INDUSTRY 4.0}

Despite the popularity and focus given to I4.0, which since its conception has arguably struggled to achieve a clear definition, even the "Industrie 4.0 Working Group" (KAGERMANN, 2015), which has been created by the German government with the objective of promoting and developing I4.0, only provides a description of the I4.0 vision and the basic enabling technologies and applications, but not a clear definition.

Furthermore, even though the I4.0 has since its conception moved up in the agenda for universities, companies and governments, the definition provided by the myriad of publications in both academic and practitioner domains has varied massively and accomplished little (BAUERNHANSL; HOMPEL; VOGEL-HEUSER, 2014).

Thus, whilst the scope of this article falls outside the engineering disciplines involved in the technology enabling I4.0, it will attempt to provide a brief overview of I4.0 from an engineering perspective in order to form a business strategy and IP strategy view of its impact.

Therefore, we begin with an overview of a key concept at the core of I4.0, the Internet of Things (IoT). A simple way to explain the IoT is to use the widespread, well-understood technological concept known as the Internet.

The Internet is comprised of a global network of interconnected computer servers, which can be accessed simultaneously by multiple users via a range of endpoint devices (mobile phones, laptops, tablets, PCs, etc.). These connected users (almost 4 billion) add source materials, access the internet and use the information contained in those servers.

The next step then is to expand the concept of connecting these users and imagine that everyday objects containing embed sensors capable of communicating information are also connected to networks and to the Internet (BELDIMAN, 2013, p. 72).

Such objects can include mobile phones, wearable devices, washing machines, light bulbs, electric cars, etc. Furthermore, in an industrial setting these include robots, machines, jet engines, etc. All of these "things" are now "smart" objects which are capable of communicating and exchanging data with the wider network about themselves (e.g., what, where, when, temperature, pressure, acceleration, speed, status, etc.), making this network the Internet of Things.

In the same fashion as the concept of I4.0, there is still no consensual definition for IoT. Nonetheless, one of the most enlightening definitions was presented by the ISOC report as:

"Internet of Things" and "IoT" refers broadly to the extension of network connectivity and computing capability to objects, devices, sensors, and items not ordinarily considered to be computers. These "smart objects" require minimal human intervention to generate, exchange, and consume data; they often feature 
connectivity to remote data collection, analysis, and management capabilities (ISOC, 2015, p. 12).

Thus, with a basic understanding of IoT, one can relate to the concept of I4.0, which can be characterised as a form of "Industrial Internet of Things" (IIoT) (LEBER, 2012). Therefore, alluding to the IoT applied in the industrial context, as already mentioned above in the form of connected robots, machines, jet engines, other equipment, etc.

This characterisation is similar to the one made by Kirazli and Hormann (2015, p. 864), which provides the following definition for I4.0: "Industry 4.0 is the systematic development of an intelligent, real-time capable, horizontal and vertical networking of humans, objects and systems."

Therefore, I4.0 is the deployment of IIoT within the boundaries of an individual business, also known as "Vertical Integration", as well as the deployment across a value chain, industry or even cross-industry, also known as "Horizontal Integration" (KAGERMANN, 2015).

To conclude this section, it is proposed that the deployment of IIoT within individual businesses, whilst undoubtedly leading to operational gains and other benefits such as increased speed, control and overall productivity, would not lead to major implications regarding the way businesses generate, protect, distribute and capture value. This is due to the fact that the knowledge and integration of all "things" and any data and knowledge exchange would remain under the control of a single entity.

On the other hand, the deployment of IIoT across value chains and/or industries, crossing individual business boundaries, will pose particular challenges, especially with regards to the strategic sharing, or not, of data and knowledge. To this end, the next few sections will explore the key implications to manufacturing businesses, as well as the need for the businesses to adapt their models and IP strategies in order to mitigate risks and secure value.

\section{THE IMPACT OF I4.0 ON BUSINESSES}

Having clarified the concept of I4.0, this section will turn to what is changing for current businesses. Why does these changes matter to businesses? And why should anyone care?

The vision of I4.0 is that integrating products, operations, businesses, supply chains and industries via the IIoT will result in a seamless product or service lifecycle and the potential to perform the exploitation of data emanating from the smart devices connected to each other and scattered in all industrial dimensions, which in turn will lead to new insights into products, operations, businesses, users and services.

Such vision, also called "digital transformation" is already taking place in many industries, where businesses are gravitating away from just selling hardware (e.g. parts, jet engines, robots, motors, etc.), and heading towards a model focused on commercialising solutions that provide a combination of hardware with embedded sensors and communication capability, generating field data and software solutions that enable users to utilise analytics to operate, 
monitor, control and maintain the hardware in a new way (e.g. preventative maintenance).

There are various estimations regarding the volume and impact on businesses and the wider economy, if such a vision is achieved (FOROOHAR, 2016, p. 18). These estimates demonstrate a substantial importance to businesses and wider society: "In 2015, there were 10 billion connected devices. (BUSINESS INSIDER, 2015). IoT will generate between US\$3.9 and US\$11.1 trillion by 2025 (MANYIKA, 2015, p. 2.).”

To illustrate the impact of the digital transformation, imagine the change in how various forms of navigation technology have evolved. The first devices for satellite navigation (Sat Navs) were simple digital versions of the old style hardware (paper maps), which in turn replaced other methods of navigation (celestial navigation with stellar maps).

The original Sat Navs offered their users a massive improvement on the way the hardware was used due to their ease to operate, to search for a destination and to track your progress to the destination. Nevertheless, the early Sat Navs were disconnected from the real world, in the sense that their core information was static and the parameters were never adjusted to reflect live conditions such as traffic or roadworks. As such, the estimated time of arrival was almost always inaccurate.

The new generation of Sat Navs came along, powered by the IoT and big data analytics, which combine for example the information from the driver's mobile phones with traffic cameras and wider emergency services information in order to accurately estimate the arrival time for each route. Furthermore, it very often also analyses all the alternative routes to your destination and provides the most effective option.

This analogy demonstrates a simplistic example of the transition from the first industrial revolution all the way to the fourth. The key point in this analogy is that the driver using the latest, fully connected Sat Nav, will inevitably have an advantage in comparison to drivers utilizing the older systems, as they will have a dynamic and efficient way to travel, which in turn will lead to faster journeys, lower fuel costs and higher reliability.

In conclusion, as in the analogy above, businesses that stay out of I4.0 are likely to be left behind and be less competitive. Furthermore, it is argued that as the benefits estimated above begin to be realised across industries and sectors, businesses will quickly embark in their digital transformation and business leaders and IP practitioners will need to use the existing structures, models and devices to generate, distribute and capture value and to stay competitive in the face of I4.0.

Having discussed the wider impact of I4.0 on businesses, attention now turns to an assessment of the implications of this transformation to Intellectual Property.

\subsection{THE INTELLECTUAL PROPERTY WORLD MAP AND BRAZIL'S DISTANCE FROM THE FOURTH INDUSTRIAL REVOLUTION PROTAGONISTS}

Brazil has advanced to the forefront of Intellectual Property Legislation, as seen with 
the Lei de Propriedade Industrial (L. 9.279/1996, amended by L. 10.196/2001), aimed at meeting the global rules regarding business relations; also contemplating the regulation of rights and obligations relating to industrial property (Decree no. 2.553/1998); also other laws that address the theme of I4.0, such as the Marco Civil da Internet (L. 12.965/2014), among several other laws, and the most recent of them, establishing the Innovation Program for Connected Education (Decree $n^{\circ}$ 9.204, November 23, 2017). Brazil also innovates with the creation of the Brazilian Association of Artificial Intelligence (ABRIA) in May, 2017, in order to map and thereby foster the Brazilian initiatives in the field of artificial intelligence.

The Brazilian jurisprudence is sensitive to internal legislative changes and also to international conventions, particularly those of which it is a signatory, in accordance with the laws recognised worldwide. Aligned with its position, the Brazilian Superior Tribunal of Justice points out that:

The Lei de Propriedade Industrial restrains the granting of trademarks: A) trade name, title or insignia (art $124 \mathrm{~V}$ and $195 \mathrm{~V}$ ); b) signs that reproduce brands the applicant could not be unaware of because of their activity, whose owner is established in a country that Brazil has an agreement with, if the brand is intended to distinguish similar or identical products or susceptible to cause confusion or brand association with such third party trademark (article 124, XXIII.); c) well-known brand in its field of activity pursuant to art. 6a (I) of the Paris Convention for Protection of Industrial Property. The Paris Convention established in 1883 gave rise to the international industrial property system in order to harmonize the protective system for the signatory countries, which include Brazil and the UK. (BRASIL, 2014, online, free translation).

There are also many studies in Brazil focused on the legal impacts arising from robotic advances, such as robots deployed to support and care for children, elderly or disabled people, as well as in surgical medicine, autonomous vehicles and drones. These themes are recurrent in the studies and scientific research in the law field, especially in regards to intellectual property law and its derivations. Indeed, in February 2017 the European Parliament adopted the report initiating the legislative process on these issues. Besides other digital issues, such as Bitcoin and Blockchain.

The economic impact brought by I4.0 and its radical changes are increasingly recurrent. Chief Data Officers (CDO) of this industry experience ever increasing amounts of transactions and data aggregation, increasing the risk of leaking private information, making it necessary to control and mitigate risks and liabilities contractually in order to ensure accountability regarding privacy and the protection of sensitive enterprise data, for example, DPOs - Data Privacy Officers, or CPOs - Chief Privacy Officers.

However, compared to the leading countries, such as the UK, the registration of patents in Brazil is far away from occupying a protagonist position, which follows the limited performance in general in Latin America as a whole, as demonstrated in the historical map (Exhibit 1 ), which depicts the size of each county according to their volume of intellectual property in 2002. Thus, although Brazil has improved massively since 2001, it is still just in the $24^{\text {th }}$ 
position in patent registration, $14^{\text {th }}$ in trademark registration and $22^{\text {nd }}$ on registered designs, according to the latest WIPO report (Exhibit 2) published in 2017 with the data collected during the year 2016.

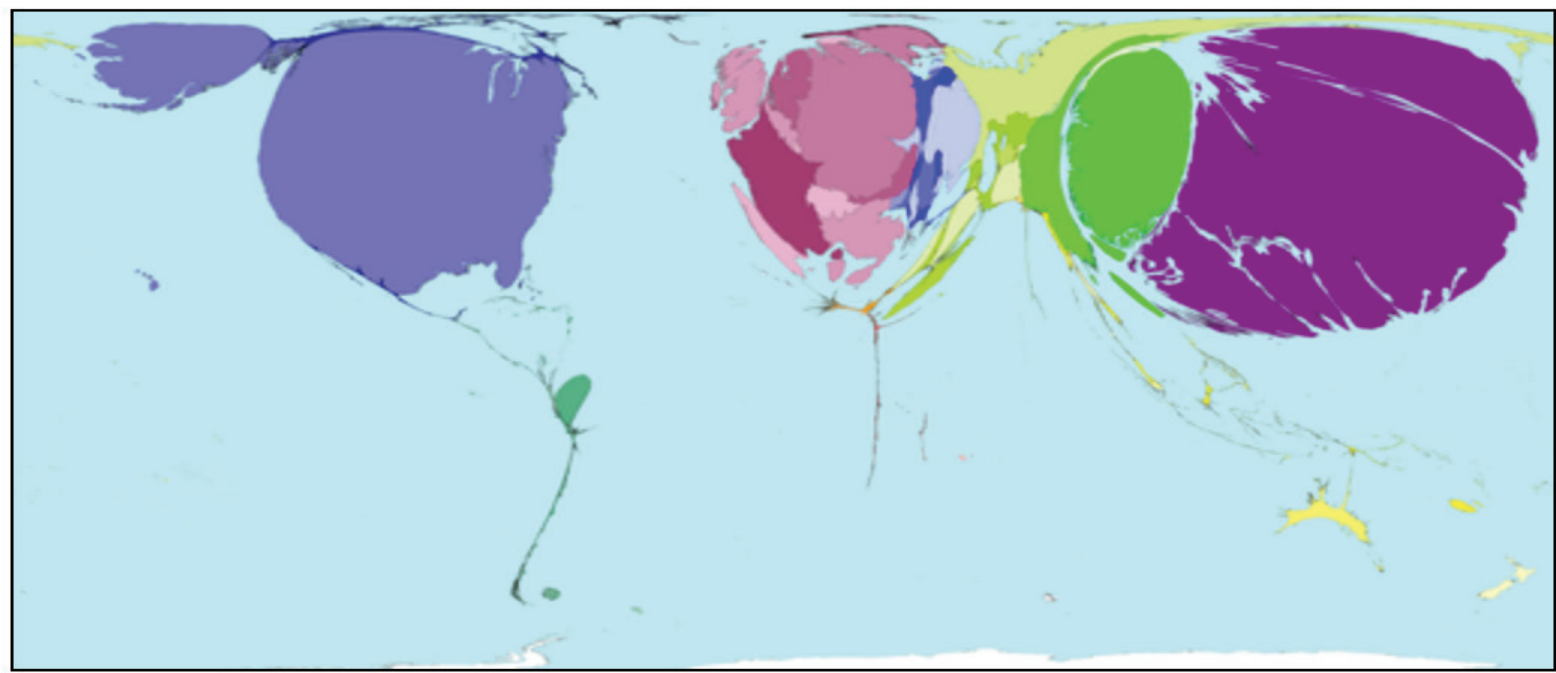

Exhibit 1 - Patents Granted in 2002 World Map

Source: SASI Group (University of Sheffield) and Mark Newman (University of Michigan) (WORLDMAPPER, 2006, online).

\begin{tabular}{|c|c|c|c|}
\hline Origin & Patents & Trademarks & Designs \\
\hline China & 1 & 1 & 1 \\
\hline U.S. & 2 & 2 & 4 \\
\hline Germany & 5 & 4 & 2 \\
\hline Japan & 3 & 3 & 7 \\
\hline Rep. of Korea & 4 & 8 & 3 \\
\hline France & 6 & 5 & 11 \\
\hline U.K. & 7 & 7 & 5 \\
\hline Italy & 11 & 11 & 9 \\
\hline Switzerland & 24 & 13 & 22 \\
\hline Brazil & & 14 & \\
\hline
\end{tabular}

Exhibit 2 - WIPO Ranking of IP filling by origin in 2016

Source: (WORLD INTELLECTUAL PROPERTY ORGANIZATION, 2017, online).

As such, I4.0 is still not a reality for most Brazilian companies, and speaking of horizontal integration strategies, it is in an even farther step. Alongside this, the Country must insist on the verification of these cutting-edge models, such as the discussions that we will initiate in this article, especially regarding the strategies for effective protection of intellectual property, just to spark the interest in breaking these barriers.

A recent example of complete transformation is China, which in the last ten (10) years moved out of the intermediary space to take the top spot in the world ranking of intellectual 
property registration. It is argued that China realized that with the advance of technology and in particular the I4.0, countries that do not care about such protection will be less competitive and place themselves out of the world's stage for exporting end products. Thus, it is also argued that some countries are and will be marginalised and be positioned as producers of raw materials and commoditised goods.

\section{INTELLECTUAL PROPERTY}

According to the World Intellectual Property Organization (WIPO), Intellectual Property (IP) can be characterised as creations of the mind (WORLD INTELLECTUAL PROPERTY ORGANIZATION, 2011). These include inventions, literary and artistic works, symbols, names, images, and designs used in commerce. IP can be categorised, according to the subject matter it covers, into two main categories: industrial property, which includes inventions, industrial designs, integrated circuit topographies, trademarks, and geographical indications; and copyright, which includes literary, dramatic and artistic works. IP-based innovation covers a wide spectrum of innovations, including drugs, machines, processes, business methods, software, maps, designs, computer chips, etc. Within this broad scope, IP can be found in any drawings, songs, books, logo, invention from an inventor and many others. IP Law provides for exclusive rights for the creators of IP. Such rights are referred to by the term intellectual property rights (IPR) (WORLD INTELLECTUAL PROPERTY ORGANIZATION, 2011).

This section explores IP protective measures and the difference between formal and informal protection measures. Protecting IP can be understood as a prohibition, which is intended to ensure that no one uses IP in a way that is contrary to the owner's will.

The protective measures can take effect in various forms, in the form of a trade secret, copyright protection, which forbids someone to reprint a book, remix a song, or patent protection, which prevents the use an invention, or trademarks, which protect the use of logos, among many other possibilities. As shown by these examples, the protection of IP can mean quite different things. However, all the possible protections of intellectual properties fall into one of the two categories: formal protection measures and informal protection measures (HOWELLS; LAITNER, 2003).

\subsection{THE IMPLICATIONS FOR INTELLECTUAL PROPERTY}

Historically, the focus of IP practitioners has been to use IP rights as the traditional "Shield and Sword" to protect the physical things, devices, structures, or the configuration of physical systems, physical outputs, or the operation of physical systems, physical connections, etc.

However, with the implementation of I4.0 the focus needs to be expanded in IP protection for intangible things, such as methodologies, configuration of virtual systems, data 
ownership, handling and storage, processing algorithms, brand recognition, etc.

The implementation of I4.0 challenges the current understanding and use of IP protection and commercialisation strategies, justifying the development of new approaches better suited to the rapidly changing, highly integrated business networks.

As a result of the implementation of interconnected communications and the utilization of application programming interfaces (APIs) to more collaborative inter-company models, businesses must carefully consider how to protect their IP, whilst at the same time facilitating the interoperability of connected businesses.

The sub-section below presents a non-exhaustive list of challenges for IP strategy in the face of this new highly collaborative and interoperable environment emanating from I4.0.

\subsection{THE INTEGRATED LIFE CYCLE - MODEL BASED DEFINITIONS}

In order to achieve the levels of integration across the product life cycle from design to recycling, the $\mathbf{1 4 . 0}$ will require a change in the nature of proprietary files. This will undoubtedly impact manufactures who will be pushed due to efficiency and market pressures, whether they like it or not, towards migrating to "Model Based Enterprises" (MBE) <http:// www.lifecycleinsights.com/tech-guide/model-based-enterprise-mbe>, where manufacturing businesses will move away from utilising 2D engineering drawings and specifications, to utilising digitalised 3D product drawings and definitions (i.e., Model Based Definitions "MBD”) (VEZZETTI; DESTEFANIS; ALEMANNI, 2011). These files can be shared across the supply chain (HEDBERG, 2016).

In fact, as highlighted by Hedberg on pg. 12, studies have demonstrated that manufacturing businesses could save millions and reduce their time to market and new product introduction time by almost $75 \%$ in average by utilising MBD.

Thus, the MBE digital files, also known as the "digital thread" or "source of truth" as referred to by Siemens (RICHTER; WALTHER, 2017), will be produced by 3D Computer Aided Design (CAD) software, which will contain the specifications for components and final products, including dimensions, tolerances and materials, as well as bills of materials and manufacturing information.

It is not difficult to imagine the potential damage caused if such files fall in the wrong hands, as this confidential information would enable a rapid copying of the product. As such, the potential loss of valuable IP obviously increases as manufacturing businesses migrate to the integrated life cycle model of I4.0 and begin to utilise the MBD files.

\subsection{DIGITAL BUSINESSES AND THE HUMAN CLOUD}

Despite the trend towards digitalization of businesses, one part of the organizations will remain unchanged, that is, the reliance on human beings to setup, coordinate and make 
decision regarding critical activities.

Of particular importance in this context is the fact that, in the current technological setting, more and more technical work is being done by suppliers, contractors or even the employees themselves, which are working remotely, which is the so called "human cloud."

This trend is a key factor in the I4.0 labour environment, where programmers, data scientist, IT professionals, statisticians, etc. provide specialized services to hundreds of projects scattered across a virtual cloud. These workers can perform their task from anywhere in the world, and the only thing necessary is to have internet access (O'CONNOR, 2015).

Furthermore, the available literature (AURIGA, 2015) points out that IT employment has the highest turnover rate compared to any other industry, reaching 20-30\% annually and only lasting from one to four years of tenure. Painting an even more aggravating picture, a report by Symantec (2013) presents evidence from a survey showing that nearly 60 percent of software developers based in the United States believe to have the right to reuse code that they have written in previous assignments for the purposes of their next employment and over 40 percent believe that they should have the IP in their inventions.

This challenge was illustrated by the legal case between Formula One teams and a service provider, namely Force India vs. Malaysia Racing (2012) EWHC 616 (Ch) and Force India v. Aerolab (2013) EWCA Civ 780.

A key issue raised on paragraph 61 of Force India vs. Arolab was the need to distinguish between the personal skill and knowledge of the employees of the service provider and the corporate trade secrets of its clients. A concern was expressed that the development contract should not "unduly restrict the ability of Aerolab's employees from making use of their skill and knowledge, even if that skill and knowledge had been enhanced by information that they had acquired in the course of working on the Force India project." (FORCE INDIA FORMULA ONE TEAM LTD, 2013, p. 12). This dispute shows the difficulties in defining the scope of protection of trade secrets in an era characterized by employee mobility and open innovation models.

In conclusion, the confluence of digitalised business and high labour mobility, in combination with the above MBD files and the vertically integrated businesses carrying a vast amount of aggregated know-how and technical information, gives rise to one of the biggest risks to business IP due to unclear ownership of rights and knowledge spill over as a result of a subsequent competitor employment.

\subsection{HORIZONTALLY INTEGRATED BUSINESSES AND THE VALUE OF DATA}

In the typical pre-I4.0 environment, IP strategies have focused on protecting hardware and software that process and store data. However, the data itself, especially in the newly interconnected environment, is of high value and worthy of protection. This value emanates from the ability to perform analytics on data from integrated smart objects, generating new 
knowledge, which can be the source of competitive advantage and innovation. As such, the rights to these data sets, as well as the bigger aggregated data sets, as well as the knowledge and insights emanating from it are of critical importance to businesses.

Data, in its more simplistic form, is typically protected by trade secrets and copyright law, saved in the case of databases under EU jurisdiction via the "sui generis" protection scheme provided by the EU Directive 96/9/EC (Directive 96/9/EC, European Parliament and Council) (EUROPA, 1996).

Although the above methods of data protection can be useful in many circumstances, they very often fall short in scope and are considered by many as non-adequate (DLA Piper, Rights in Data Handbook) (DLA PIPER, 2013, p. 46.). In this case, it is very likely that businesses and IP practitioners will have to resort to contractual agreements in order to govern the operation and the inter-company relations in the I4.0 environment.

Therefore, IP strategies will have to take account of the required contractual agreements surrounding data exchange, particularly addressing the types, rights, and licensing constructs related to 14.0 interconnected data.

After discussing some of the challenges in relation to Intellectual Property in this new industrial paradigm, attention now turns to the need to adapt the current IP strategies.

\section{THE NEED TO ADAPT IP STRATEGIES}

With the current rate of technological and industrial change, and the unpredictable nature of technologies involved in the I4.0 environment, a variety of techniques should be utilised in order to effectively identify and protect IP. While there are a number of common strategies to be deployed in the arena, it is important to emphasize that a one-size-fits-all solution does not exist, as each individual business performs to achieve its own strategic objectives and will be setup according to a particular business model. As such, it is recommended that various legal mechanisms be considered alternatively or concurrently, with the non-legal mechanisms as part of a comprehensive IP strategy.

This section will be split into two sub-sections, covering first the non-legal recommendations about Organisational Strategies. The second subsection will then explore a set of recommendations related to the three IP challenges raised above.

\subsection{BUSINESS STRATEGY RECOMMENDATIONS}

IP management involves a lot more than just law and legal knowledge. Even so, IP management is very commonly left to a particular technical or legal department within the business. Such department will typical only focus on the protection of the business from potential infringement of other businesses IP and the protection from the infringement of its IP by competitors. It is argued that this approach to IP management, albeit marginally relevant 
to business, is nevertheless unable to deliver tangible benefits and income to businesses, as there is too much emphasis on protection and on the legal issues, but not sufficient emphasis on the commercial aspects and the role of IP in the wider business strategy.

In order to bridge the IP and Business strategy, the team responsible for IP management must be not only competent in legal matters related to IP but also competent and directly involved in the business strategy and long-term objectives. The Handbook of European Intellectual Property Management uses an example of a technology company to illustrate this point.

In the example, the technology company identifies that a given market is shifting to a position where another technology company has a strong patent portfolio. In this case, typically a specialist team member from the legal department should flag the potential issue, provide evidence and offer advice to the business regarding a particular strategy to enter this market. At the same time, a senior IP specialist may devise and propose a strategy for the company to achieve particular agreements with competitors, in order to utilise their patents and reduce the risks and development costs in exchange for some of the company's own IP.

A significant problem occurs when businesses neglect IP management and fail to allocate relevant resources to monitor the potential markets in which the business plans to enter, as well as the IP landscape. Furthermore, businesses often also fail by delegating the IP management to inappropriate areas of the business. For example, if strategic decisions regarding IP management are delegated to operational level IP experts, such decisions are likely to be unsuccessful, as the employee is often unable to reach appropriate conclusions due to insufficient knowledge of the business and its strategies.

In addition, the typical approach in most businesses it that the IP experts are only called upon when it is too late and the problem has already occurred or when the business has already infringed the IP rights of another business or if another business has infringed their IP rights.

On the other hand, it is argued that by integrating IP strategies with the business strategies, a business can make effective decisions as the part of the managerial responsibility, thus transforming IP into a real asset and an important resource adding value to the business.

Nevertheless, it is a challenge to change the current practices, which arguably are driven by the senior management perception of IP as a very complex and time-consuming area, which should be entrusted to subject area experts within the in-house legal departments or external third parties. Furthermore, it is argued that this is also the main reason for the tendency to neglect the importance of IP and to link it to the wider business strategy.

Another challenge to businesses, as argued in the European Handbook of Intellectual Property Management, is the fact that it is very difficult to recruit people with the right capabilities in this area and able to effectively assume the role of an IP manager or executive. Furthermore, even if someone would succeed, they would become a significant drain on the wage budget. The employee must be competent in legal, technical and business aspects. Most IPR managers today have technical education combined with a degree in patent law, but they lack training and practical experience in business. A good example of how difficult it is to find 
an employee who has all the necessary skills is one of the largest Danish companies, which had its position of IPR executive vacant for 18 months.

There are several solutions available. The management can either engage potential talents who are already employed in the company, invite them to strategy seminars, challenge them on the issue of IPR and its significance in various fields, and send them on courses, or pay external consultants to spar with the management.

\subsubsection{A look at competitors' patents}

An appropriate IP strategy focuses not only on balancing the business own IP rights, but also on dealing with those from competitors. These represent an important but highly underestimated information channel, which provides valuable insight into which products the competitors can be expected to develop during the next five years.

An ineffective approach to solving the task is to completely refrain from patenting and worrying about competitors' patents. The promising approach, on the other hand, is to make efforts to translate competitors' patent applications into something that is of relevance to one's own business. The competitors' applications may in fact influence your decision about the next product you may introduce into the market. Again, it is crucial for a company's competitive edge to have an IPR executive who not only has insight into technical and legal areas, but is also a skilled businessperson.

This is also highly relevant in cases where mergers and acquisitions are on the agenda. Here, a traditional legal approach would consist of focusing solely on assessing whether the company that is being acquired has any potential or ongoing legal proceedings due to patent infringements. However, the IPR executive should play a much more central role in these cases, and already at an early stage evaluate whether the intellectual property rights of the other company have commercial relevance for their own business. Patents and other intellectual property rights can be worthless, if competitors have something better, and assessments of this sort require more than just legal expertise. They require that the person responsible for IPR is part of the management team.

\subsubsection{The growing importance of IPR}

Working with IPR poses significant challenges for a company, firstly in finding the right person for the job and secondly in managing effectively its IPR. We often see companies facing these challenges by burying their heads in the sand. However, this can turn out to be a costly affair because globalization means that the focus on patents and other intellectual property rights is continuously increasing in importance.

Globalisation means that it is highly unlikely that you will identify a local need that does not already exist elsewhere in the world. Presumably, somewhere in the world, someone else will be in the process of developing something in order to meet that same need. Therefore, 
it is important to have an IP strategy ready as soon as you have a new product or production process.

\subsection{INTELLECTUAL PROPERTY RECOMMENDATIONS: LIFE CYCLE RECOMMEN- DATIONS}

In order to mitigate the potential risks of utilising MBDs in inter-organisational collaborations, businesses should be particularly careful when sharing files. The next three recommendations form a non-exhaustive list, which is generic and applicable in most cases where a MBD model is shared. Nevertheless, each individual business should ensure that the information shared contributes to the business goals and objectives.

\subsubsection{Always use NDAs (non-disclosure agreements)}

MBD files should only be shared after the parties have signed a suitable and effective NDA. Such agreement must clearly define the term 'Confidential Information' as including electronic information such as, but not limited to, MBD models and associated files.

\subsubsection{Always share only the necessary layers information}

Businesses should pay particular attention to how much detail is shared within the interconnected value networks. Each file should be configured specifically for the purpose for which it is going to be shared. For example, a particular supplier may need the details regarding a component inside a product, but not the model for the whole product. Thus, the files should be suited for the different uses so that the unnecessary parts of the product design are masked (UK-IPO, 2015, p. 33).

\subsubsection{Always use confidentiality notices}

Business should include confidentiality notices in all documents before sharing. Such notices should at least include the business name and the word confidential "[Company] Confidential" in the MBD file name. It is also a best practice to embed a proprietary notice in the file to be shared, for example:

The information contained herein is the confidential and proprietary property of [Company]. It is to be used only for the benefit of [Company] and shall not be disclosed, transferred, reproduced, altered, or used for any purpose without the express prior written consent of [Company] (MILLIEN; GEORGE, 2016, p. 21).

As mentioned above, these three recommendations are not exhaustive and attention should be given to the particular relationship between the parties sharing and receiving the 
files, as well as any other protection that may be available in case of misappropriation of intellectual property.

\subsection{HUMAN CLOUD RECOMMENDATIONS}

In order to address the risks related to knowledge spillover in relation to high labour mobility and the vertically integrated businesses carrying a vast amount of aggregated know-how and technical information, business should consider at least the following two actions:

\subsubsection{Use non-disclosure clauses in employment and contractor contracts}

Businesses should ensure that contractual agreements for both employees and contractors contain non-disclosure clauses. Furthermore, these contracts should also include an IP assignment clause specifying the ownership of IP at the first point of engagement.

\subsubsection{Implementation and physical security measures}

Businesses should ensure that adequate security controls are in place, preventing not only physical risks (document management, disabling USBs, etc.), but also IT risks (network monitoring, data loss software). These security controls should prevent the access to source code files, MBD files, design specifications and other IP-rich documents.

It is also important to remember that these security measures must be implemented in accordance with the particular jurisdiction, particularly the national and regional laws governing employee privacy, inventor remuneration and limitations on employee invention ownership.

\subsection{DATA SHARING RECOMMENDATIONS}

Data sharing is one of the most critical aspects of the Fourth Industrial Revolution. The vast amounts of data to be shared and aggregated across the entire value chain is particularly important as the rights to the individual data sets, as well as the bigger aggregated data sets and the knowledge emanating from them are of critical importance to businesses. As such, we lay out a non-exhaustive set of recommendations with the three basic actions, which will improve the business IP protection.

\subsubsection{Categorize the different data types}

Businesses should be aware of the main data types to be shared in the inter-organisational relationships emanating from Industry 4.0. Furthermore, contractual terms between businesses exchanging data should address at least the following data types: 
a) raw data, machine data and unprocessed data:

- this is simply the big data sets that are collected from the relevant smart objects at issue in the IoT-related contract;

b) processed data:

- this is the set of data resulting from the analysis of the raw data by any actor (suppliers, manufacturers, customers, end-users) in the Industry 4.0 environment and;

c) input data:

- this is any data that is entered by the end-users who interact with the relevant smart objects at issue (and/or their respective customers).

\subsubsection{Data ownership rights}

Businesses should also be aware of the different data ownership rights in relation to inter-organisational data exchange. Once more, contractual agreements in this area should address at least the following points:

a) the smart object manufacturer may simply own the data regardless of whether the smart object itself is sold or leased to a customer;

b) the smart object manufacturer may own the data, but the customer will receive a license to some or all of the data;

c) the smart object manufacturer may own the data, but the customer and some third parties will receive a license to some or all of the data or;

d) the customer may own the data, but the smart object manufacturer will receive a license to some or all of the data and for all or some specific purposes.

\subsection{IP OWNERSHIP CLAUSES}

Finally, businesses should also consider the fact that, similar to joint IP ownership clauses, data rights provisions in Industry 4.0 related contracts will be the subject of a lot of negotiation, which often times will likely be contentious negotiations as the powers of the various parties in a value chain will influence how much each party will give in. Nevertheless, such contracts should at least consider the following licensing constructs surrounding IP: What data? What rights? What IP? Who owns the IP? Who are the licensor and the licensee? What is the particular business model? What products, services or areas of use? In what territory? What is the term (time) of such right? Are the rights exclusive or non-exclusive? Is there a right to sublicense?

These constructs should be incorporated into the particular contractual agreements. The following is an example of an ownership clause where a "smart object manufacturer owns the raw and processed data, but the customer receives a license to some of the data.

The Customer acknowledges and agrees that the Manufacturer owns all rights, 
titles and interest in the Equipment Data. The Customer will upon request deliver such data to the Manufacturer. The Manufacturer hereby grants the Customer a perpetual, non-exclusive, non-transferable, royalty-free license to use, reproduce and store the Equipment Data solely to the extent required to operate Customer's equipment (MILLIEN; GEORGE, 2016, p. 22).

Furthermore, in this case it is critical to provide a clear definition of equipment data as in the following example:

Equipment Data means any data, metadata, logs or other information generated by the operation of the Software or the Device, but does not include any personally identifiable information, nor any information entered into the Software or the Device by the Customer's employees, agents or end-users, except to the extent where portions of such information appear in anonymized or aggregated form or in automated logs or similar records through the normal operation of the Software. (MILLIEN; GEORGE, 2016, p. 22).

Finally, in the Industry 4.0 inter-organisation relations, data from suppliers and customers will often aggregate data from other devices generated by a particular business. It is also important to define expectations, responsibilities and liabilities regarding data security and privacy, as both suppliers and customers may be vulnerable to breaches of data security and privacy.

Therefore, contracts about this must be made as clearly and carefully as possible. They should include the details regarding the gathering, anonymizing, notifying and using customer and supplier data.

\section{CONCLUSION}

The phenomenon of 14.0 will reach businesses of all sizes and across all industries, which will generate rich data that, when coupled with analytics, will enable more efficient monitoring and controlling of operations leading to increased levels of flexibly and efficiently.

While these new technology offers and business models have no effect on IP rights themselves, they do affect how IP strategies should be formulated. That is, the basic requirements for their registration and enforcement of IP obviously remain unchanged. But the practices and strategies for securing and commercialising IP in such environment are completely different.

The interconnected supply chain allows devices in different businesses to work together to provide new functionality and/or data analytics to businesses throughout the supply chain, as well as customers. Flexibility imparted to products through their increased data processing and communication capabilities creates uncertainty when it comes to IP protection. A flexible and multi-faceted IP strategy informed by the business strategy and business model must be implemented to ensure control over the business value offer, as well as the brand, technology ownership, reputation and joint technological innovation, while preserving options for fast route to market, configuration and customisation in light of the involvement of multiple businesses within the Industry 4.0 value chain. 


\section{INDÚSTRIA 4.0: ESTRATÉGIAS DE INTEGRAC̣ÃO HORIZONTAL E DIREITO DE PROPRIEDADE INTELECTUAL NA INGLATERRA}

\section{RESUMO}

A Propriedade Intelectual (PI) é cada vez mais reconhecida como um ativo intangivel primordial que influencia o valor das empresas, as estratégias corporativas e a sua gestão. Este artigo enfoca o impacto da implementação da Indústria 4.0 (I4.0) no gerenciamento de IP nas redes colaborativas interligadas interorganizacionais. Tais redes interligadas permitirão que grupos de empresas, muitas vezes concorrentes e/ou clientes, compartilhem dados e colaborem na concepção, desenvolvimento e fabricação de produtos e/ou serviços complexos, trocando grandes quantidades de dados técnicos proprietários. Além disso, este trabalho explora o modo como as empresas podem se beneficiar das capacidades de rede interconectadas, protegendo-se de qualquer risco a respeito da vulnerabilidade de recursos IP até apropriação indevida, uso não autorizado ou vazamento. $\mathrm{O}$ foco deste estudo é a indústria de fabricação do Reino Unido, onde ferramentas contratuais formais estão sendo implantadas para apoiar o gerenciamento de PI em projetos colaborativos. Baseia-se em um estudo aprofundado das práticas de gerenciamento de PI na cadeia de fornecimento de manufatura do Reino Unido para avaliar criticamente o estado atual da prática, a fim de fornecer respostas aos riscos que emanam do gerenciamento de PI nesta configuração colaborativa nova e complexa. Este artigo conclui que a PI e as ferramentas contratuais implantadas neste novo ambiente devem ser sustentadas pela estratégia de negócios e pelo modelo de negócios. Além disso, as mudanças nas estruturas organizacionais são necessárias para reunir funções que normalmente operam em silos em muitas empresas de fabricação, notadamente: engenharia, tecnologia da informação, departamentos comerciais e jurídicos.

Palavras-chave: Quarta Revolução Industrial. Propriedade Intelectual. Estratégia de Negócio. Estratégia de Propriedade Intelectual.

\section{INDUSTRIA 4.0: ESTRATEGIAS DE INTEGRACIÓN HORIZONTAL Y DERECHO DE PROPIEDAD INTELECTUAL EN INGLATERRA}

\section{RESUMEN}

La Propiedad Intelectual (PI) es cada vez más reconocida como un activo intangible primordial que influye en el valor de las empresas, en las estrategias corporativas y en su gestión. Este artículo se centra en el impacto de la implementación de la Industria 4.0 (I4.0) en la administración de PI en las redes cooperativas interconectadas interorganizacionales. Estas redes interconectadas permitirán que grupos de empresas, a menudo competidores y/o clientes, 
compartan datos y colaboren en el diseño, desarrollo y fabricación de productos y/o servicios complejos, intercambiando grandes cantidades de datos técnicos registrados. Además, este trabajo explora la forma en que las empresas pueden beneficiarse de las capacidades de red interconectada, protegiéndose de cualquier riesgo sobre la vulnerabilidad de recursos de la PI la apropiación indebida, el uso no autorizado o la filtración. El enfoque de este estudio es la industria de fabricación del Reino Unido, donde se están implementando herramientas contractuales formales para apoyar la administración de la PI en proyectos colaborativos. Se basa en un estudio exhaustivo de las prácticas de administración de la PI en la cadena de suministro de manufactura del Reino Unido para evaluar críticamente el estado actual de la práctica, con el fin de proporcionar respuestas a los riesgos que emanan de la administración de la PI en esta configuración colaborativa nueva y compleja. Este artículo concluye que la PI y las herramientas contractuales implantadas en este nuevo ambiente deben ser respaldadas por la estrategia de negocios y el modelo de negocios. Además, los cambios en las estructuras organizativas son necesarios para reunir funciones que normalmente operan en silos en muchas empresas de fabricación, especialmente: ingeniería, tecnologías de la información, departamentos comerciales y jurídicos.

Palabras clave: Cuarta Revolución Industrial. Propiedad intelectual. Estrategia de negocio. Estrategia de Propiedad Intelectual.

\section{REFERENCES}

AURIGA. Employee Tenure Becomes Hot Topic for Tech Companies. 2015. Available at: <http://auriga.com/blog/.>. Access in: 20 May 2018.

BAUERNHANSL, T.; HOMPEL, M. Ten; VOGEL-HEUSER, B. (Eds.). Industrie 4.0 in Produktion, Automatisierung und Logistik. Wiesbaden: Springer, 2014.

BELDIMAN, D. Introduction. In: BELDIMAN, D. (Ed.). Access to Information and Knowledge: 21st Century Challenges in Intellectual Property and Knowledge Governance. Cheltenham (UK)/Northampton, MA: Edward Elgar, 2013.

BOTTHOF, A. Zukunft der Arbeit im Kontext von Autonomik und Industrie 4.0. In: BOTTHOF, A.; HARTMANN, E. A. (Eds.). Zukunft der Arbeit in Industrie 4.0. Berlin, Heidelberg: Springer, 2015. p. 3-8.

BRASIL. Superior Tribunal de Justiça. REsp 1190341/RJ. Relator: Ministro Luis Felipe Salomão, Quarta Turma, j. 05/12/2013. DJe, 28 fev. 2014. Disponível em: <http://www.stj.jus.br/SCON/jurisprudencia/doc.jsp?livre=REsp+1190341\&b=ACOR\&p=true\&l=10\&i=5>. Acesso em: 4 jun. 2018.

BRETTEL, M. et al. How virtualization, decentralization and network building change the 
manufacturing landscape: an industry 4.0 perspective. International Journal of Mechanical, Aerospace, Industrial and Mechatronics Engineering, v. 8, n. 1, p. 37-44, 2014. BUSINESS INSIDER. The Internet of Things 2015 Report. [S.1.: s.n.], 2015.

DLA PIPER. Rights in Data Handbook. [S.1.: s.n.], 2013.

EIGHT GREAT TECHNOLOGIES. The Internet of things: a patent overview. The Intellectual Property Office (UK), 2014.

EMMRICH, V. et al. Geschäftsmodell-Innovation durch Industrie 4.0: chancen und Risiken für den Maschinen- und Anlagenbau. München, Stuttgart: Dr. Wieselhuber \& Partner, Fraunhofer IPA, 2015.

EUROPA. European Parliament and of the Council. Directive 96/9/EC. Official Journal of the European Communities, 11 Mar. 1996.

FORCE INDIA FORMULA ONE TEAM LTD. v. 1. Malaysia Racing Team SDN BHD and others. EWHC 616 (Ch). 2012. Available at: <https://www.withersworldwide.com/ en-gb/force-india-formula-1-team-limited-v-1 malaysia-racing-team-sdn-bhd-ors $>$. Access in: 4 June 2018.

FORCE INDIA FORMULA ONE TEAM LTD. Aerolab SRL and others. EWCA Civ 780. 2013.v. 1. Available at: <https://www.casemine.com/judgement/ uk/5a8ff7b060d03e7f57eb140f >. Access in: 4 June 2018.

FOROOHAR, R. The 1 Thing on Everybody's Mind at Davos, Time.com (Jan. 20, 2016). HEDBERG, T. Testing the Digital Thread in Support of Model-Based Manufacturing and Inspection. Journal of Computing and Information Science in Engineering, v. 16, n. 2, 2016.

HOWELLS, M.; LAITNER, J. A Technical framework for industrial GHG mitigation in developing countries. Proceedings: Summer Study: Industrial Energy Efficiency. New York: ACEEE, 2003.

JONDA, M. Innovation, Geschäftsmodell: "analyse - und planungsprozesse der strategischen unternehmensführung.” Saarbrücken: VDM Müller, 2007.

KAGERMANN, H. Change through digitization: value creation in the age of industry 4.0. In: ALBACH, H. et al. (Eds.). Management of Permanent Change. New York: Springer, 2015. p. 23-45.

KIRAZLI, A.; HORMANN, R. A conceptual approach for identifying Industrie 4.0 application scenarios. In: INDUSTRIAL AND SYSTEMS ENGINEERING RESEARCH CONFERENCE, 2015, Geórgia, EUA. Proceedings... Geórgia, EUA: Institute of Industrial Engineers, 2015. 
LEBER, J. General Electric Pitches an Industrial Internet. MIT Technology Review, 28 Nov. 2012.

LOEBBECKE, C.; PICOT, A. Reflections on societal and business model transformation arising from digitization and big data analytics: A research agenda. The Journal of Strategic Information Systems, v. 24, n. 3, p. 149-157, 2015.

MAN, J. C. de; STRANDHAGEN, J. O. An Industry 4.0 research agenda for sustainable business models. In: CIRP CONFERENCE ON MANUFACTURING SYSTEMS, 50., 2017, Taichung City, Taiwan. Proceedings... Taichung City, Taiwan: Elsevier B.V. Procedia CIRP 63, 2017. p. 721-726. 2017. Doi:10.1016/j.procir.2017.03.315.

MANYIKA, J. The Internet of Things: Mapping the value beyond the hype. McKinsey Global Institute, p. 2, June 2015.

MILLIEN, R.; GEORGE, C. Intellectual Property Lawyering in the Fourth Industrial Revolution (the IoT). 2016. Available from: <https://www.researchgate.net/publication/313504500_Intellectual_Property_Lawyering_in_the_Fourth_Industrial_Revolution_ the_IoT > Access in: 4 June 2018.

O'CONNOR, S. The human cloud: a new world of work. Financial Times, 8 Oct. 2015.

RICHTER, K.; WALTHER, J. Supply Chain Integration Challenges in Commercial Aerospace. A Comprehensive Perspective on the Aviation Value Chain. [S.l.: s.n.], 2017.

SCHWAB, K. The fourth industrial revolution: what it means, how to respond. World Economic Forum. [S.1.]: Crown Business, 2016.

SYMANTEC. What's yours is mine: how employees are putting your intellectual property at risk. 2013. Available at: <https://www.symantec.com/content/en/us/about/media/ pdfs/b-whats_yours_is_mine.en-us.pdf>. Access in: 4 June 2018.

THE INTERNET SOCIETY (ISOC). Overview. 2015. Available at: <https://www.internetsociety.org/wp-content/uploads/2017/08/ISOC-IoT-Overview-20151221-en.pdf>. Access in: 4 June 2018.

UK-IPO. Intellectual Property Office: annual report and accounts 2014 to 2015. Printed: UK, Majesty's Stationery Office. 2015. Available at: <https://www.gov.uk/government/publications/ipo-annual-report-and-accounts-2014-to-2015>. Access in: 4 June 2018.

VEZZETTI, E.; DESTEFANIS, F.; ALEMANNI, M. Model-based definition design in the product lifecycle management scenario. The International Journal of Advanced Manufacturing Technology, v. 52, n. 1/4, p. 1-14, 2011.

WORLD INTELLECTUAL PROPERTY ORGANIZATION. Intellectual Property Report. 2011. Available at: <www.wipo.int/export/sites/www/freepublications/en/intproperty/944/wipo_pub_944_2011.pdf>. Access in: 4 June 2018. 


\section{WORLD INTELLECTUAL PROPERTY ORGANIZATION. World Intellectual Property}

Indicators 2017. Geneva: World Intellectual Property Organization, 2017. Available at: <http://www.wipo.int/edocs/pubdocs/en/wipo_pub_941_2017.pdf>. Access in: 11 Feb. 2017.

WORLDMAPPER. SASI Group (University of Sheffield) and Mark Newman (University of Michigan). Patents Granted in 2002 World Map. 2006. Available at: <http://www.worldmapper.org/display.php?selected=167>. Access in: 10 Feb. 2017. 